Original article

\title{
SEROPREVALENCE OF BLUETONGUE DISEASE VIRUS (BTV) AMONG DOMESTIC RUMINANTS IN KOSOVO AND FIRST RECORD OF BTV SEROTYPE 4 IN SHEEP
}

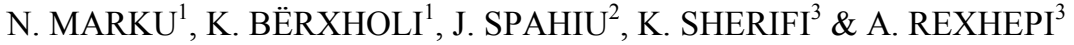 \\ ${ }^{1}$ Agricultural University of Tirana, Faculty of Veterinary Medicine, Tirana, \\ Albania; ${ }^{2}$ Food and Veterinary Agency, Kosovo; ${ }^{3}$ University of Prishtina \\ Hasan Prishtina, Faculty of Agriculture and Veterinary Medicine, Kosovo
}

\section{Summary}

Marku, N., K. Bërxholi, J. Spahiu, K. Sherifi \& A. Rexhepi, 2019. Seroprevalence of bluetongue disease virus (BTV) among domestic ruminants in Kosovo and first record of BTV serotype 4 in sheep. Bulg. J. Vet. Med., 22, No 1, 50-56.

\begin{abstract}
The objective of the study was to estimate the seroprevalence and serotype of bluetongue virus (BTV) in domestic ruminants in different regions in Kosovo, in years 2014 and 2015. A total of 905 blood sera were analysed: 633 from sheep, 204 from cattle and 68 from goats, collected in 170 farms, 88 villages in 18 municipalities. All samples were analysed with c-ELISA for detection of BTV seroprevalence. From sheep with clinical signs samples were collected and were analysed with specific RT-PCR. Out of all 905 samples analysed with c-ELISA, 105 samples (11.6\%) were seropositive (53 ovine, 39 bovine and 13 caprine). The 43 samples from sheep with clinical sings for bluetongue disease were confirmed by RT-PCR, and BTV-4 serotype was identified. The results indicated high seroprevalence of BTV in domestic ruminants, evidence of BTV-4 serotype in sheep, suggesting a need to strengthen national and regional scientific efforts and control strategy to meet the global challenge of this infectious disease.
\end{abstract}

Key words: bluetongue, BTV-4, domestic ruminants, Kosovo, seroprevalence

\section{INTRODUCTION}

Bluetongue is an insect-transmitted viral disease of domestic and wild ruminants (Mertens et al., 2004). Bluetongue virus (BTV) is a RNA virus, belonging to the non-contagious vectorborne Orbivirus, family Reoviridae. Twenty-six BTV serotypes of the virus are reported (Maan et al., 2012). Multiple BTV serotypes (serotypes $1,2,4,6,8,9,11$ and 16) have in- vaded Europe since 1998 (Mellor et al., 2009; Rodriguez-Sanchez et al., 2008). Bluetongue disease with clinical signs was reported in Kosovo in 2001, caused by BTV-9 serotype (Osmani et al., 2006).

The BTV is transmitted between its ruminant hosts by certain species of biting midges of the genus Culicoides (Darpel et al., 2007). There are approximately 30 
Culicoides species that play a role in the transmission of BTV across the world (Meiswinkel et al., 2004; 2007). Presence of Culicoides containing C. obsoletus and C. pulicaris complexes but not $C$. imiciola is reported in Kosovo (Berisha et al., 2010).

The global distribution of individual BTV serotypes is attributed to climate change and human influence in environment (Randolph, 2008; Maclachlan, 2010), involving different mechanisms in introduction process including the movement of infected livestock, the passive movement of infected Culicoides by the wind (Wilson \& Mellor, 2009).

The virus can infect most species of domestic and wild ruminants, but in domestic sheep clinical signs are usually most severe. Cattle are the main reservoir for the BTV, although the cattle and goats disease usually assumes a subclinical course without severe symptoms (Darpel et al., 2007). Serotype-specific vaccines for BTV, inactivated or live-attenuated are currently available (Savini et al., 2008; Zientara et al., 2010).

The seroprevalence of BTV using cELISA was reported in many studies, and it is probably the most widely used and validated method with high sensitivity and specificity (Hamblin, 2004). Sensitive and specific real-time RT-PCR assays have been developed to detect BTV types, targeting different genome-segment as reviewed by Hoffmann et al. (2009). Realtime RT-PCR assay for BTV-4 targeting genome segment 2 , is reported to be a sensitive and reliable method for the identification and differentiation of the twentysix BTV serotypes (Maan et al., 2012).

The purpose of this research is to assess the distribution, seroprevalence and BTV serotype in domestic ruminants (sheep, cattle and goats) in Republic of Kosovo.

\section{MATERIALS AND METHODS}

Samples were collected in 88 villages in 18 municipalities (Klina, Gjilan, Gjakova, Shtërpcë, Kaçanik, Drenas, Dragash, Viti, Deçan, Mitrovica, Skenderaj, Shtime, Hani i Elezit, Lipjan, Vushtrri, Peja, Novobërda and Prizren) from a total of 170 farms. The total number of serum samples collected was 905, including 633 from sheep, 68 from goats, and 204 from cattle. Samples were taken during May-September in 2014 and 2015.

Serum samples were separated from sheep blood and were kept frozen at $-20{ }^{\circ} \mathrm{C}$ until used for detection of BTVspecific IgG. The testing of sera was performed by the competitive-enzyme-linked immunosorbent assay (c-ELISA) for detection of BT antibodies in ruminant sera using a commercial test (IDEXX ${ }^{\circledR}$, Westbrook, USA). Tests were conducted according to manufacturer instructions, with the known positive and negative controls tested on each plate.

The 59 blood samples collected from sheep with clinical signs for bluetongue were also tested using type-specific realtime RT-PCR assay for BTV-4 targeting genome segment 2, for the presence of this serotype in the samples tested. Molecular analyses were done at the Pirbright Institute, UK.

Composition of reaction mixes for one-step real-time RT-PCR in total volume of $15 \mu \mathrm{L}$ contained: EXPRESS SuperScript ${ }^{\circledR}$ qPCR SuperMix Universal (10 $\mu \mathrm{L})$, Forward primer $(0.4 \mu \mathrm{L})$, Reverse primer $(0.4 \mu \mathrm{L})$, Probe $(0.8 \mu \mathrm{L})$, RNase free water $(1 \mu \mathrm{L}), \operatorname{ROX}(1 / 10$ dilution) $(0.4 \mu \mathrm{L})$, and EXPRESS SuperScript ${ }^{\circledR}$ $\operatorname{mix}(2 \mu \mathrm{L})$.

The primers for RT-PCR and thermal profile are presented in Tables 1 and 2 . 
Seroprevalence of bluetongue disease virus (BTV) among domestic ruminants in Kosovo ....

Table 1. Primers and probes used for one-step RT-PCR of bluetongue virus (Hofmann et al., 2008)

\begin{tabular}{lllc}
\hline $\begin{array}{l}\text { Primer/ } \\
\text { probe }\end{array}$ & Oligo name & Sequence (5'-3') & $\begin{array}{c}\text { Working } \\
\text { concentra- } \\
\text { tion }(\mu \mathrm{M})\end{array}$ \\
\hline $\begin{array}{l}\text { For- } \\
\text { ward }\end{array}$ & Hofm_BTV_IVI_F2 & TGGAYAAAGCRATGTCAAA & 20 \\
$\begin{array}{l}\text { Reverse } \\
\text { Probe }\end{array}$ & Hofm_BTV_IVI_R2 & ACRTCATCACGAAACGCTTC & 20 \\
& Hofm_BTV_IVI_P & $\begin{array}{l}\text { FAM-ARGCTGCATTCGCATCGTACGC- } \\
\text { Tamra }\end{array}$ & 5 \\
\hline
\end{tabular}

Table 2. Real time RT-PCR thermal profile

\begin{tabular}{lccc}
\hline Stage of real-time RT-PCR & Temperature & Duration & Number of cycles \\
\hline Reverse transcription & $50^{\circ} \mathrm{C}$ & $15 \mathrm{~min}$ & 1 cycle \\
RT inactivation/ & $95^{\circ} \mathrm{C}$ & $20 \mathrm{~s}$ & 1 cycle \\
Taq activation & $95^{\circ} \mathrm{C}$ & $3 \mathrm{~s}$ & \\
PCR & $56^{\circ} \mathrm{C}$ & $30 \mathrm{~s}$ & 45 cycles \\
& $72^{\circ} \mathrm{C}^{*}$ & $30 \mathrm{~s}^{*}$ & \\
\hline
\end{tabular}

*Read fluorescence at the end of this stage.

\section{RESULTS}

\section{Clinical observations}

In summer 2014, clinical symptoms indicative of bluetongue were observed in sheep herds in most of regions in Kosovo. The clinical findings were typical for the disease: abundant salivation, oedema of the tongue, buccal and intermaxillary regions, erosive stomatitis, elevated body temperature, coronitis with resulting lameness. Clinical symptoms of the bluetongue disease were observed in infected cattle as well.

\section{Serological analysis}

All samples were analysed by c-ELISA test. The BTV antibodies were detected in 105 from 905 samples (11.6\%). Seropositive samples for BTV antibodies are detected in all domestic ruminants: sheep $(8.3 \%)$, goats $(19.1 \%)$ and cattle $(19.1 \%)$ (Table 3).

\section{RT-PCR analysis}

The 43 seropositive samples were tested positive by RT-PCR. The RNA samples were also tested using type-specific realtime RT-PCR targeting genome Seg-2 for BTV-4. Results confirmed the BTV-4 serotype. 
Table 3. Results from samples analysed with c-ELISA for BTV taken in sheep, cattle and goats in different municipalities in Kosovo in 2014 and 2015

\begin{tabular}{|c|c|c|c|c|}
\hline Municipality & Animal species & $\begin{array}{c}\text { Number of } \\
\text { samples }\end{array}$ & Positive cases & $\%$ \\
\hline \multirow[t]{2}{*}{ Skenderaj } & Sheep & 28 & 0 & $0.0 \%$ \\
\hline & Sheep & 24 & 3 & $12.5 \%$ \\
\hline \multirow{2}{*}{ Gjilan } & Goat & 9 & 5 & $55.6 \%$ \\
\hline & Cattle & 14 & 8 & $57.1 \%$ \\
\hline Gjakova & Sheep & 16 & 1 & $6.3 \%$ \\
\hline Shtërpc & Cattle & 20 & 4 & $20.0 \%$ \\
\hline \multirow[t]{2}{*}{ Kaçanik } & Sheep & 43 & 4 & $9.3 \%$ \\
\hline & Goat & 2 & 0 & $0.0 \%$ \\
\hline Drenas & Sheep & 24 & 1 & $4.2 \%$ \\
\hline Dragash & Sheep & 28 & 0 & $0.0 \%$ \\
\hline \multirow[t]{3}{*}{ Viti } & Sheep & 118 & 21 & $17.8 \%$ \\
\hline & Goat & 12 & 3 & $25.0 \%$ \\
\hline & Cattle & 6 & 3 & $50.0 \%$ \\
\hline \multirow[t]{2}{*}{ Deçan } & Sheep & 32 & 0 & $0.0 \%$ \\
\hline & Goat & 3 & 0 & $0.0 \%$ \\
\hline Mitrovicë & Goat & 9 & 0 & $0.0 \%$ \\
\hline Shtime & Cattle & 12 & 0 & $0.0 \%$ \\
\hline Hani i Elezit & Sheep & 16 & 2 & $12.5 \%$ \\
\hline \multirow[t]{2}{*}{ Lipjan } & Sheep & 9 & 0 & $0.0 \%$ \\
\hline & Goat & 23 & 1 & $4.3 \%$ \\
\hline Vushtrri & Cattle & 86 & 8 & $9.3 \%$ \\
\hline \multirow[t]{2}{*}{ Prizren } & Sheep & 28 & 4 & $14.3 \%$ \\
\hline & Cattle & 20 & 7 & $35.0 \%$ \\
\hline \multirow{2}{*}{ Ferizaj } & Sheep & 141 & 1 & $0.7 \%$ \\
\hline & Cattle & 46 & 9 & $19.6 \%$ \\
\hline \multirow[t]{2}{*}{ Novobërda } & Sheep & 55 & 13 & $23.6 \%$ \\
\hline & Goat & 10 & 4 & $40.0 \%$ \\
\hline Peja & Sheep & 71 & 3 & $4.2 \%$ \\
\hline Total & & 905 & 105 & $11.6 \%$ \\
\hline
\end{tabular}

The distribution of BTV seropositive (red dots) and BTV seronegative samples (blue dots) in farms and villages of Kosovo is shown on Fig. 1.

\section{DISCUSSION}

This report describes the first evidence of BTV-4 in sheep in Kosovo as well as BTV seroprevalence in domestic rumi- nants in years 2014 and 2015. After the first BT disease outbreak reported in 2001 caused by BTV serotype 9 (Osmani et al., 2006), in disease outbreak in 2014 in Kosovo the results of this study confirmed high seroprevalence in domestic ruminants of $11.6 \%: 8.3 \%$ in sheep, $19.1 \%$ in goats and $19.1 \%$ in cattle. The RT-PCR analysis in samples from sheep with clinical signs confirmed presence of BTV se- 


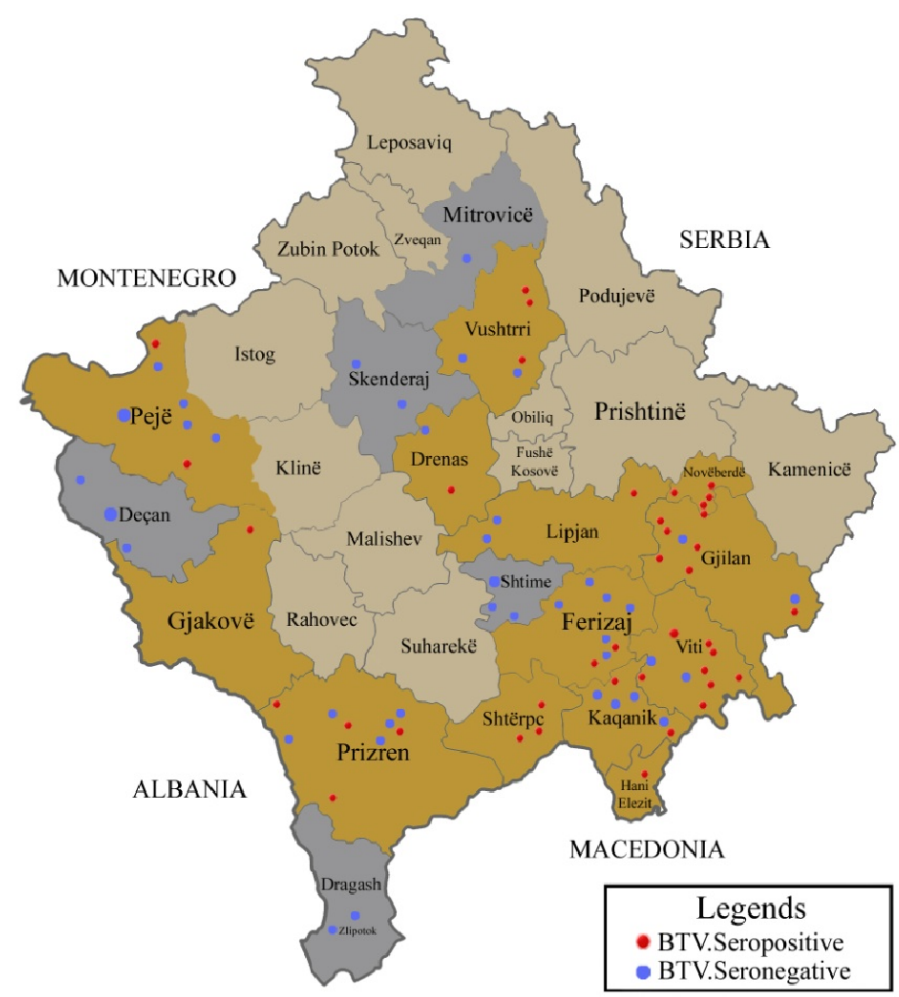

Fig. 1. The BTV seropositive (red dots) and seronegative (blue dots) samples in domestic ruminants in different municipalities in Kosovo in 2014 and 2015.

rotype 4 involved in disease outbreak in year 2014. Both BTV-4 and BTV-9 serotypes are reported to be present in European countries (Mellor et al., 2009; Rodriguez-Sanchez et al., 2008).

The high seroprevalence of specific antibodies in domestic ruminants, the presence of disease vectors, presence of two serotypes BTV-9 and BTV-4 in domestic ruminants in Kosovo, suggest that this disease should already considered as endemic disease in Kosovo. Detection and distribution of BTV positive samples showed that the virus was widespread in different areas within the country.

The bluetongue disease is considered a major problem for veterinary medicine due to the rapid spread, mortality and incurred economic losses (Baylis \& Mellor, 2001; Saegerman et al., 2008).

There is still no contingency plan for responding to an outbreak of bluetongue disease in Kosovo. The high rate of seroprevalence and identification of current two BTV serotypes (BTV-4 and BTV-9) suggests the need for the application of control measures for BTV in Kosovo and strengthening regional scientific efforts and control strategy for infectious diseases in animals. Further research studies are necessary to analyse different mechanisms that have been involved in the introduction process, spread of the virus, specific vector of BTV in our country, factors as- 
sociated with animals and environment, factors influencing in disease outbreak, and its impact on animal production.

\section{ACKNOWLEDGEMENTS}

The authors would like to thank the Food and Veterinary Agency in Kosovo, for the support on infrastructural facilities provided for laboratory for diagnostics and reports.

\section{REFERENCES}

Baylis, M. \& P. S. Mellor, 2001. Bluetongue around the Mediteranean in 2001. Veterinary Record, 149, 659.

Berisha, B., I. Goga, B. Hulaj, D. Çaushi, K. Sherifi, A. J. Wilsmore \& W. P. Taylor, 2010. Entomological research on the vectors of bluetongue disease and the monitoring of activity of Culicoides in the Prishtinë region of Kosova. Veterinaria Italiana, 46, 431-437.

Darpel, K. E., C. A. Batten, E. Veronesi, A. E. Shaw, S. Anthony, K. Bachanek-Bankowska, L. Kgosana, A. Bin-Tarif, S. Carpenter, U. U. Müller-Doblies, H. H. Takamatsu, P. S. Mellor, P. P. C. Mertens \& C. A. L. Oura, 2007. Clinical signs and pathology shown by British sheep and cattle infected with bluetongue virus serotype 8 derived from the 2006 outbreak in northern Europe. The Veterinary Record, 161, 253-261.

Hamblin, C., 2004. Bluetongue virus antigen and antibody detection, and the application of laboratory diagnostic techniques. Veterinaria Italiana, 40, 538-545.

Hofmann, M., C. Griot, V. Chaignat, L. Perler \& B. Thür, 2008. Blauzungunkrankheit erreicht die Schweiz. Schweizer Archiv für Tierheilkunde, 150, 49-56.

Hoffmann, B., M. Beer, S. M. Reid, P. Mertens, C. A. Oura, P. A.van Rijn, M. J. Slomka, J. Banks, I. H. Brown, D. J. Alexander \& D. P. King, 2009. A review of RT-PCR technologies used in veterinary virology and disease control: sensitive and specific diagnosis of five livestock diseases notifiable to the World Organisation for Animal Health. Veterinary Microbiology, 139, 1-23.

Maan, N. S., S. Maan, M. N. Belaganahalli, E. N. Ostlund, D. J. Johnson, K. Nomikou \& P. C. Mertens, 2012. Identification and differentiation of the twenty six bluetongue virus serotypes by RT-PCR amplification of the serotype-specific genome segment 2. PLoS ONE, 7, e32601. doi:10.1371/journal.pone.0032601.

Maclachlan, N. J., 2010. Global implications of the recent emergence of bluetongue virus in Europe. Veterinary Clinic of North America: Food Animal Practice, 26, 163171.

Meiswinkel, R., L. M. Gomulski, J. C. Del'ecolle, M. Goffreda \& G. Gaspari, 2004. The taxonomy of Culicoides vector complexes-unfinished business. Bluetongue, Part I. Veterinaria Italiana, 40, 151-159.

Meiswinkel, R., P.van Rijn, P. Leijs \& M. Gofredo, 2007. Potential new Culicoides vector of bluetongue virus in northern Europe. The Veterinary Record, 161, 564 565.

Mellor, P., M. Baylis \& P. Mertens, 2009. Bluetongue. Academic Press, London.

Mertens, P. P. C., J. Diprose, S. Maan, K. P. Singh, H. Attoui \& A. R. Samuel, 2004. Bluetongue virus replication, molecular and structural biology. Veterinaria Italiana, 40, 426-437.

Osmani, A., B. Murati, Q. Kabashi, I. Goga, B. Berisha, A. J. Wilsmore \& C. Hamblin, 2006. Evidence for the presence of bluetongue virus in Kosovo between 2001 and 2004. The Veterinary Record, 158, 393 396.

Randolph, S., 2008. Tick-borne encephalitis virus, ticks and humans: Short term and long-term dynamics. Current Opinion in Infectious Disease, 21, 462-467.

Rodriguez-Sanchez, B., I. Iglesias-Martin \& M. Martinez-Aviles, 2008. Orbiviruses in 
Seroprevalence of bluetongue disease virus (BTV) among domestic ruminants in Kosovo ....

the Mediterranean basin: Updated epidemiological situation of bluetongue and new methods for the detection of BTV serotype 4. Transboundary and Emerging Diseases, 55, 205-214.

Saegerman, C., D. Berkvens, P. S. Mellor, 2008. Bluetongue epidemiology in the European Union. Emerging Infectious Diseases, 14, 539-544.

Savini, G., N. J. MacLachlan, J. M. SanchezVizcaino \& S. Zientara, 2008. Vaccines against bluetongue in Europe. Comparative Immunology Microbiology and Infectious Diseases, 31, 101-120.

Wilson A. J. \& Ph. S. Mellor, 2009. Bluetongue in Europe: Past, present and future. Philosophical Transactions of the Royal Society B Biological Sciences, 364, 26692681.

Zientara, S., N. J. MacLachlan, P. Calistri, J. M. Sanchez-Vizcaino \& G. Savini, 2010.
Bluetongue vaccination in Europe. Expert Review of Vaccines, 9, 989-991

Paper received 19.01.2017; accepted for publication 07.04.2017

\section{Correspondence:}

\author{
Agim Rexhepi \\ Faculty of Agriculture and \\ Veterinary Medicine, \\ 10000 Bill Clinton str., \\ Prishtina, Kosovo, \\ phone: +37744171780 \\ email: agim.rexhepi@uni-pr.edu
}

